\title{
Prey size of salmonid fishes in streams, lakes, and oceans
}

\author{
Ernest R. Keeley and James W.A. Grant
}

\begin{abstract}
The growth rate of salmonid fishes is typically fastest in oceans, intermediate in lakes, and slowest in streams. We compiled literature data to test whether differences in the size of prey eaten by salmonids in the three habitats could account for these differences in growth rate (i.e., the prey-size hypothesis). In all three habitats, salmonid fishes exhibited ontogenetic niche shifts from feeding primarily on invertebrates when small to feeding on fishes when large. Contrary to the prey-size hypothesis, invertebrates eaten in streams were larger than those eaten in lakes or oceans, whereas fish eaten in oceans were smaller than those eaten in streams or lakes. Consistent with the prey-size hypothesis, salmonids began eating fish at a smaller size in oceans $(8 \mathrm{~cm})$ than in lakes $(15 \mathrm{~cm})$ or streams $(27 \mathrm{~cm})$. However, the size at which salmonids became predominantly piscivorous $(31 \mathrm{~cm})$ did not differ significantly between habitats. We suggest that the difference in growth potential between the three habitats is partly related to the size at which fish first enter the diet.
\end{abstract}

Résumé : Le taux de croissance des poissons salmonidés est typiquement le plus rapide dans les océans, intermédiaire dans les lacs et le plus faible dans les cours d'eau. Une compilation de données de la littérature a permis de vérifier si les différences dans les tailles des proies mangées par les salmonidés dans ces trois habitats peuvent expliquer les variations dans les taux de croissance (i.e. l'hypothèse de la taille des proies). Dans les trois habitats, les salmonidés ont opéré un glissement ontologique de niche, se nourrissant d'invertébrés lorsqu'ils sont petits et, une fois grands, de poissons. Contrairement à ce que prédit l'hypothèse de la taille des proies, les invertébrés consommés dans les cours d'eau sont plus grands que ceux mangés dans les lacs ou les océans, alors que les poissons consommés dans les océans sont plus petits que ceux pris dans les lacs et les cours d'eau. En accord avec l'hypothèse, cependant, les salmonidés commencent à manger des poissons à une taille plus petite dans les océans $(8 \mathrm{~cm})$ que dans les lacs $(15 \mathrm{~cm})$ ou les cours d'eau $(27 \mathrm{~cm})$. Néanmoins, la taille à laquelle les salmonidés deviennent en prédominance des piscivores $(31 \mathrm{~cm})$ ne diffère pas significativement d'un habitat à l'autre. Nous posons l'hypothèse que la différence du potentiel de croissance entre les trois habitats est reliée à la taille à laquelle les poissons commencent à faire partie du régime alimentaire.

[Traduit par la Rédaction]

\section{Introduction}

Salmonid fishes live in a variety of habitats that can be conveniently classified as streams, lakes, and oceans (Scott and Crossman 1973). While all individuals spawn in fresh water, there is considerable variation in how much time is spent in their natal habitat (Hoar 1976; Randall et al. 1987). At one extreme, some populations complete their life cycle within a stream or lake, while others routinely migrate between two or three of the habitat types (Scott and Crossman 1973; Hoar 1976).

Evolutionary explanations for these often spectacular migrations usually focus on strategies to increase growth rate and, ultimately, reproductive success (Gross 1987).

Received September 28, 2000. Accepted March 5, 2001.

Published on the NRC Research Press Web site on May 3, 2001.

$\mathrm{J} 16000$

E.R. Keeley. ${ }^{1}$ Department of Biological Sciences, Box 8007, Idaho State University, Pocatello, ID 83209, U.S.A.

J.W.A. Grant. Department of Biology, Concordia University, 1455 de Maisonneuve Boulevard West, Montréal,

QC H3G 1M8, Canada.

${ }^{1}$ Corresponding author (e-mail: keelerne@isu.edu).
Salmonid fishes typically grow faster in lakes than in streams (Bachman 1982; Hutchings 1986; but see Gulseth and Nilssen 1999) and oceans than in fresh water (Gross 1987; Økland et al. 1993). Two hypotheses, which are not mutually exclusive, have been proposed to explain why salmonids grow faster in some habitats than in others: (1) differences in overall productivity or (2) differences in mean prey size available. For example, the migration of salmonids to oceans and the resulting increase in growth rate is thought to be related to the greater productivity of marine versus freshwater ecosystems in north-temperate latitudes (Gross et al. 1988). The prey-size hypothesis seems to originate from studies of salmonids in fresh water, in which details of their feeding biology are well known. Because of the energetic advantage of feeding on larger prey (e.g., Kerr 1971; Wańkowski and Thorpe 1979), salmonids grow larger when large prey are available (Martin 1970; Trippel and Beamish 1993; Mittelbach and Persson 1998). Moreover, the slow growth of salmonids that often occurs in streams (Bachman 1982) and sometimes in lakes (Konkle and Sprules 1986) is thought to occur because of a lack of suitable prey sufficiently large to sustain further growth (Kerr 1971). To increase the size of salmonids for trophy fishing, large prey, such as Mysis spp. or forage fish, were often introduced into lakes, even though such introductions typically 
decreased the overall yield of the target population (Northcote 1991; Rasmussen et al. 1990).

Despite hundreds of individual studies of the diet of salmonid fishes, no general synthesis of their feeding biology in different habitats is available. We decided to focus on two variables that are often quantified and, hence, comparable in many studies: the taxonomic composition of the diet and the mean prey size eaten. In addition, we use the latter to test the prey-size hypothesis. If prey size is the primary factor responsible for variation in the growth rate in salmonid fishes, then prey size should follow the trends in growth potential of the three habitat types (i.e., oceans > lakes > streams). In particular, salmonid fishes may switch to eating fish at a smaller size in oceans than in lakes or streams. Because ontogenetic shifts in diet are almost universal in fishes (Werner and Gilliam 1984), including salmonids (Keeley and Grant 1997; Mittelbach and Persson 1998), we take an allometric approach when comparing the prey size in the three habitats. We also compare the allometric trends in salmonid prey size with morphological constraints, such as gill-raker spacing and mouth size, which may limit the minimum size of prey eaten (Wańkowski 1979; Damsgård 1995), and with general allometric relationships for animals (Cohen et al. 1993).

\section{Materials and methods}

\section{Literature search and data collection}

We searched the literature for studies reporting quantitative descriptions of the diet of salmonid fishes that are commonly referred to as charr, salmon, and trout. We began by searching volumes 154 of the Canadian Journal of Fisheries and Aquatic Sciences (formerly the Journal of the Fisheries Research Board of Canada), volumes 63-96 of the Fishery Bulletin of the U.S. National Marine Fisheries Service, volumes 1-17 of the North American Journal of Fisheries Management, and volumes 51-126 of the Transactions of the American Fisheries Society. We compiled all articles that mentioned some aspect of the diet of a salmonid fish and examined all other available articles on diet that were cited by the articles in our original search.

Because we hypothesized that body size would be an important determinant of prey size, we collected data only from studies that provided a paired measurement of the body size of a salmonid fish and its prey. We used predator and prey lengths as our measures of size in all analyses, because these were the most commonly available data. Most studies reported the length of a fish as fork length rather than as total length. In the few studies where authors did not specify which length measurement was used, we assumed they were using fork length. In cases where the mass of a fish was given but not the length, we used species-specific length-mass regressions from Carlander (1969) to convert mass into length. We did not use studies that reported prey size in mass, because of the great variability in length-mass regressions between groups of invertebrates. Only studies that reported size estimates of the majority of prey items in the diet of a fish were included.

In recording data from published studies, we used the average lengths of the predator and prey, when authors reported these values in summary statistics, or interpolated numerical values from figures. If a range of predator and prey sizes were reported but not means, we used the midpoint in our analyses. In cases where two or more size- or age-classes of fish were reported, we included a datum for each class of fish. Similarly, if more than one species was examined by a particular study, we recorded a datum for each species. Our method of extracting data allowed us to include more than one datum per study but guarded against over-representing intensive studies in the data set. Because our method ignores interindividual variability in diet within populations (e.g., see McLaughlin et al. 1994), our predictive relationships represent differences between the typical individuals in different populations.

Diet composition was also compiled from studies providing quantitative measures of predator and prey lengths. We used the average number of different types of prey in fish stomachs to quantify diet composition, because it was the most common method in the literature. Because studies varied widely in the precision of the taxonomic identification of stomach contents, we categorized prey as fish, crustaceans, insects, and other (mollusks, plants, amphibians, mammals, and detritus). For each size category of fish in a particular study, we recorded the average percentage of the stomach contents comprising each of these four categories. Habitat was included as a categorical variable in the analyses: streams-any freshwater lotic habitat; lakes - any freshwater lentic habitat; and oceans-any marine habitat, including estuaries.

\section{Statistical analyses}

The relationship between predator size and prey size was investigated using an ordinary least-squares (OLS) regression for predictive relationships and reduced major axis (RMA) regression for descriptive analyses (McArdle 1988). We used the standard error of the OLS regression to approximate the standard error of the RMA regression as recommended by Sokal and Rohlf (1995). Because body-size distributions tend to be lognormally distributed, we $\log _{10}$-transformed body size variables to meet the assumption of homogeneity of variance. We compared the predator-length versus prey-length data with two morphological constraints that may limit the size range of prey for salmonid fishes. Damsgård's (1995) allometric equation for maximum prey length for brown trout (Salmo trutta; prey length $(\mathrm{cm})=0.535$ predator length $(\mathrm{cm})-0.487)$ was used to predict the upper limit of prey size, whereas Wańkowski's (1979) allometric equation of gill-raker spacing for Atlantic salmon (Salmo salar; gill-raker spacing $(\mathrm{mm})=0.115$ fork length $(\mathrm{cm})$ ) was used to predict the lower limit of prey size. We used logistic regression to predict the shift from an invertebrate to a fish diet that often happens as fish grow (Mittelbach and Persson 1998). We defined fish as piscivores in two ways: if there were any fish in the diet or if fish accounted for $\geq 60 \%$ of the diet.

The data presented in the figures represent untransformed values. For some comparisons, we replotted arithmetic relationships from the literature on a logarithmic scale. We used $\alpha=0.05$ as a critical level of significance. Residuals of final regression models were examined for consistency of error variance across the full range of all independent variables.

\section{Results}

We used data from 93 different studies, representing 19 species or subspecies of salmonid fishes (Table 1). Of these 93 studies, 39, 32, and 23 described fish from streams, lakes, and oceans, respectively. There were six different geographic regions represented in the data set, $76.1 \%$ of the observations came North America, 16.2\% from Europe, $2.7 \%$ from New Zealand, $0.6 \%$ from Australia, 2.7\% from Japan, and $1.2 \%$ from Scandinavia. Any single study contributed an average of $1.1 \%$ of the observations to the data set, and never contributed more than $13.6 \%$ of the total number of observations in the data set.

\section{Prey composition}

Eighty-one studies provided information on the taxonomy of organisms in the diet of salmonid fishes, based on the 
Table 1. Scientific and common names of salmonid fishes used in analyses of prey composition and prey size, and reference sources for data.

\begin{tabular}{|c|c|c|c|}
\hline Scientific name & Common name & Source $(\mathrm{s})^{a}$ for composition & Source $(\mathrm{s})^{a}$ for size \\
\hline Hucho hucho & Danube salmon & 63,90 & $63,80,90$ \\
\hline Oncorhynchus clarki & Cutthroat trout & 65 & 73,89 \\
\hline Oncorhynchus clarki clarki & Coastal cutthroat trout & 69 & 69 \\
\hline Oncorhynchus clarki pleuriticus & Colorado River cutthroat trout & 9 & 9 \\
\hline Oncorhynchus gorbuscha & Pink salmon & $6,31,34,44,47,62$ & $6,31,35,47,62$ \\
\hline Oncorhynchus keta & Chum salmon & $6,26,31,44,53,62$ & $6,26,31,35,41,62$ \\
\hline Oncorhynchus kisutch & Coho salmon & $6,10,11,25,43,61,62,91$ & $11,43,61,62,70$ \\
\hline Oncorhynchus masou ishikawai & Red-spotted masu salmon & & 64 \\
\hline Oncorhynchus mykiss & Rainbow trout & $5,8,12,20,36,38,42,57,65,68,71,76,79,83,85,92$ & $2,5,8,32,42,55,57,68,76,79$ \\
\hline Oncorhynchus nerka & Sockeye salmon & $4,11,74,79$ & $21,35,79$ \\
\hline Oncorhynchus tshawytscha & Chinook salmon & $5,10,13,25,27,46,57,72,75,78$ & $11,17,27,56,75,78$ \\
\hline Salmo salar & Atlantic salmon & $18,22,45,60,84$ & $3,18,22,45,60,84$ \\
\hline Salmo trutta & Brown trout & $7,14,23,28,30,32,33,37,40,48,49,66,77$ & $2,7,14,30,32,37,33,48,49,55,77$ \\
\hline Salvelinus alpinus & Arctic charr & $15,51,59$ & 59 \\
\hline Salvelinus confluentus & Bull trout & & 81 \\
\hline Salvelinus fontinalis & Brook trout & $1,4,50,54,76,84,92$ & $4,54,76,84$ \\
\hline Salvelinus leucomaenis & Japanese charr & 29 & \\
\hline Salvelinus malma & Dolly Varden & 65,91 & 81 \\
\hline Salvelinus namaycush & Lake trout & $16,19,39,52,58,67,82,86,87,88$ & $16,24,52,58,86,93$ \\
\hline
\end{tabular}

${ }^{a}$ Sources of data are defined by numbers as follows: 1, Allan (1981); 2, Allan and Malmqvist (1989); 3, Allen (1940); 4, Allen and Claussen (1960); 5, Angradi and Griffith (1990); 6, Bailey et al. (1975); 7, Bannon and Ringler (1986); 8, Bisson (1978); 9, Bozek et al. (1994); 10, Brodeur (1989); 11, Brodeur (1991); 12, Bryan and Larkin (1972); 13, Cadwallader and Eden (1981); 14, Campbell (1979); 15, Cavalli and Chappaz (1996); 16, Christie et al. (1987); 17, Craddock et al. (1976); 18, Cunjak (1992) and R.A. Cunjak, unpublished data, University of New Brunswick, Fredericton, N.B.; 19, Eck and Wells (1986); 20, Efford and Tsumura (1973); 21, Eggers (1982); 22, Egglishaw (1967); 23, Elliott (1967); 24, Elrod and O' Gorman (1991); 25, Emmett et al. (1986); 26, Feller and Kaczynski (1975); 27, Field-Dodgson (1988); 28, Frost and Smyly (1952); 29, Furukawa-Tanaka (1985); 30, Garman and Nielsen (1982); 31, Gerke and Kaczynski (1972); 32, Glova and Sagar (1991);

33, Glova et al. (1992); 34, Godin (1981); 35, Healey (1991); 36, Hodgson et al. (1991); 37, Hubert and Rhodes (1992); 38, Hubert et al. (1994); 39, Hudson et al. (1995); 40, Hunt and Jones (1972); 41, Irie (1987); 42, Irvine and Northcote (1982); 43, Johnson and Ringler (1981); 44, Kaczynski et al. (1973); 45, Keeley and Grant (1997); 46, Kjelson et al. (1982); 47, Kocik and Taylor (1987); 48, L'Abée-Lund et al. (1992); 49, LaVoie and Hubert (1994); 50, Magnan and Fitzgerald (1982); 51, Malmquist et al. (1992); 52, Martin (1970); 53, Mason (1974); 54, McLaughlin et al. (1994); 55, McLennan and MacMillan (1984); 56, Merkel (1957); 57, Metz (1974); 58, Miller and Holey (1992); 59, Moore and Moore (1974); 60, Morgan et al. (1986); 61, Mundie (1971); 62, Murphy et al. (1987); 63, Nagy (1976); 64, Nakano (1995); 65, Northcote et al. (1979); 66, O’Donoghue and Boyd (1932); 67, Olson et al. (1988); 68, Parkinson et al. (1989); 69, Pearcy et al. (1990); 70, Peterson et al. (1982); 71, Pidgeon (1981); 72, Reid (1961); 73, Reimchen (1990); 74, Ricker (1937); 75, Rondorf et al. (1990); 76, Rose (1986); 77, Sagar and Eldon (1983); 78, Sagar and Glova (1987); 79, Schneindervin and Hubert (1987); 80, Shnavevich and Moshuk (1957) (cited from Holcík et al. 1988); 81, L. Sulek, J.S. Baxter, and E.B. Taylor, unpublished data, University of British Columbia, Vancouver, B.C.; 82, Swedberg and Peck (1984); 83, Tabor et al. (1996); 84, Thonney and Gibson (1989); 85, Tippets and Moyle (1978); 86, Trippel and Beamish (1993); 87, Van Vliet and Qadri (1970); 88, Van Oosten and Deason (1937); 89, Wilzbach et al. (1986); 90, Witkowski and Kowalewski (1984); 91, Wolf et al. (1983); 92, Wurtsbaugh et al. (1975); 93, Yule and Luecke (1993). 
Fig. 1. Mean (+SE) percentage of the number of prey in stomachs of salmonid fishes in relation to body size (10-cm size intervals) for populations from streams $(a)$, lakes $(b)$, and oceans (c). Percent composition according to different taxonomic categories is defined by the following bar types: solid, fish; open, insects; hatched, crustaceans; cross-hatched, other (mollusks, plants, amphibians, mammals, and detritus combined). Data are compiled from 81 different studies. Numbers represent sample sizes (i.e., the number of studies contributing a datum for that size category and habitat type).

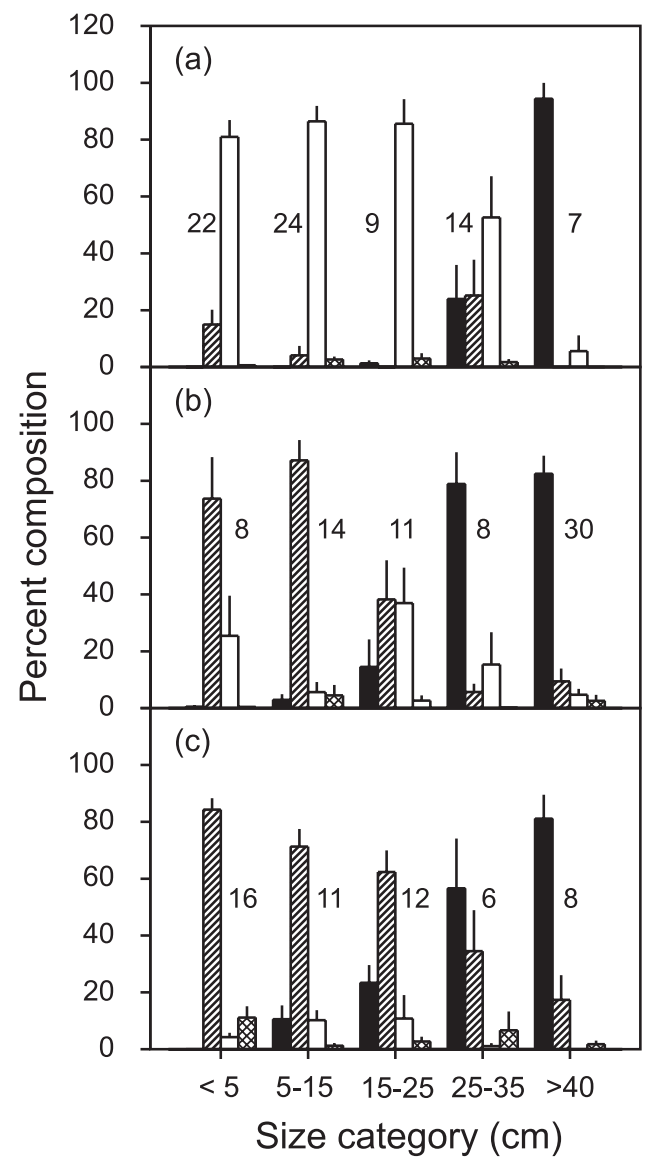

numerical frequency of prey items (Table 1). The precision of prey taxonomy varied widely among studies. Important differences in prey composition were evident between the three habitats, even using our simple categories of prey type. Insects were the dominant type of invertebrate prey in streams, whereas crustaceans were the dominant type in lakes and oceans (Fig. 1). When paired by size category, the percentage of insects consumed was greater in streams than in either lakes (paired $t=3.42, n=5, P=0.027$ ) or oceans (paired $t=4.16, n=5, P=0.014$ ). The percentage of crustaceans consumed by salmonids was greater in oceans than in streams (paired $t=3.45, n=5, P=0.026$ ) but did not differ between oceans and lakes (paired $t=1.42, n=5, P=0.23$ ) or between lakes and streams (paired $t=1.89, n=5$, $P=0.13)$. The percentage of fish consumed did not differ significantly among the three habitats (analysis of variance (ANOVA), $F_{2,12}=0.14, P=0.87$ ).

In streams, the percentage of insects in the diet decreased with increasing fish size $(r=-0.64, n=72, P<0.0001$;
Fig. 2. (a) The probability of observing any fish in the diet of salmonid fishes according to body length and habitat. The broken line and solid triangles represent fish from oceans, the solid line and open circles represent fish from lakes, and the dotted line and solid circles represent fish from streams. Symbols represent the mean proportion for each $10-\mathrm{cm}$ size interval. The logistic regression for any fish in the diet is $\operatorname{logit}(p)=6.13 \log _{10}$ salmonid length $(\mathrm{cm})+1.57$ habitat $-10.32, n=196$,

$P<0.0001$, where habitat is 1 for streams, 2 for lakes, and 3 for oceans. Arrows indicate the body length when half the fish will contain some fish in their stomachs: $8.4 \mathrm{~cm}$ in oceans, $15.0 \mathrm{~cm}$ in lakes, and $26.9 \mathrm{~cm}$ in streams. (b) The logistic regression for a dominant percentage $(\geq 60 \%)$ of fish in the diet is logit $(p)=$ $11.25 \log _{10}$ salmonid length $(\mathrm{cm})-17.81, n=196, P<0.0001$. Symbols as in $a$. Half the fish will contain primarily fish in their stomachs at a body length of $30.8 \mathrm{~cm}$.

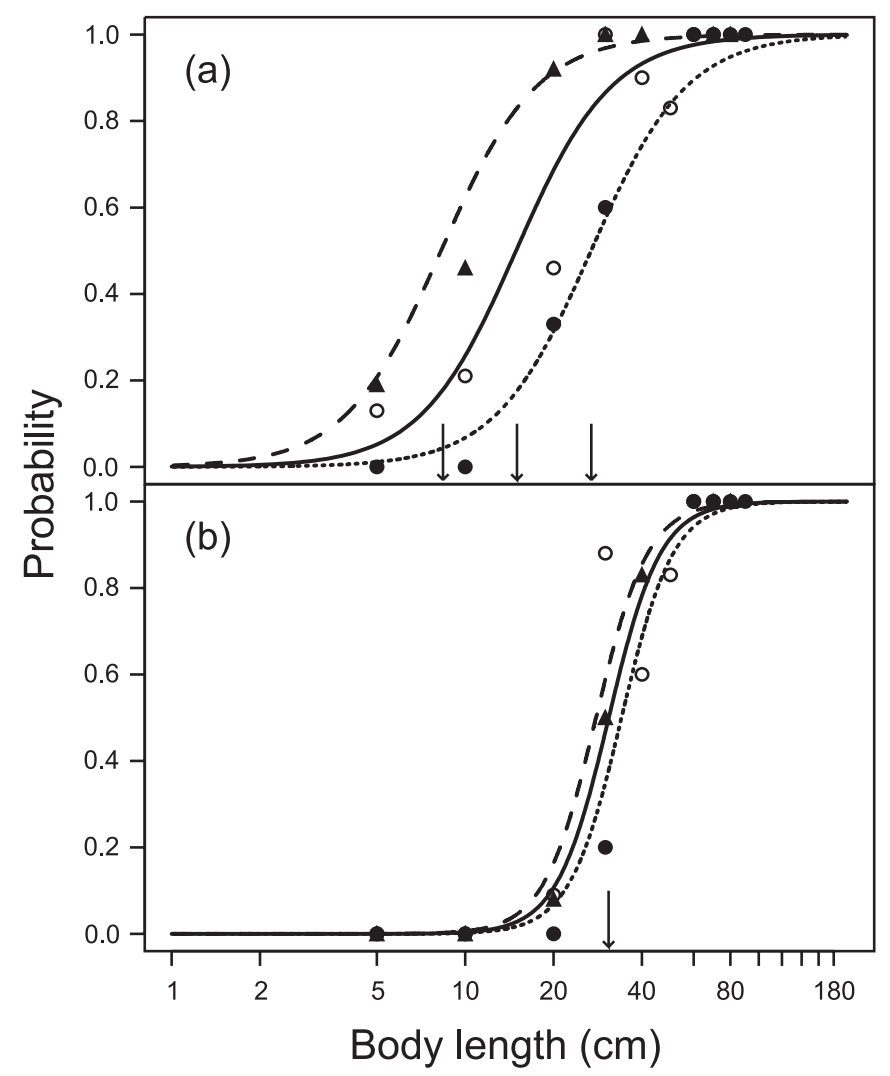

Fig. 1a) and the percentage of crustaceans in the diet was not related to fish length $(r=-0.10, n=72, P=0.39$; Fig. 1a). The percentage of crustaceans in the diet decreased as fish size increased for both lakes $(r=-0.70, n=71, P<$ 0.0001 ; Fig. $1 b)$ and oceans $(r=-0.67, n=53, P<0.0001$; Fig. 1c). The percentage of insects in the diet also decreased with increasing fish length both in lakes $(r=-0.25, n=71$, $P=0.040$; Fig. $1 b)$ and in oceans $(r=-0.30, n=53, P=$ 0.027 ; Fig. 1c).

The percentage of fish in the diet increased with fish length for streams $(r=0.87, n=72, P<0.0001)$, lakes $(r=$ $0.79, n=71, P<0.0001)$, and oceans $(r=0.78, n=53$, $P<0.0001)$. The probability of observing any fish in the diet increased with increasing fish length $\left(\chi^{2}=51.92, n=\right.$ $196, P<0.0001)$. However, fish appeared in the diet at a 
Fig. 3. The relationships between the size of salmonid fishes and their prey. The dotted line and solid circles represent stream fish feeding primarily on invertebrates: $\log _{10}$ prey length $(\mathrm{mm})=0.85 \log _{10}$ predator length $(\mathrm{cm})-0.23 \log _{10}$ predator length $(\mathrm{cm})+0.033(n=100$, $\left.P<0.0001, R^{2}=0.55\right)$. The solid line and solid squares represent lake fish feeding primarily on invertebrates: $\log _{10}$ prey length $(\mathrm{mm})=$ $0.32 \log _{10}$ predator length $(\mathrm{cm})-0.089\left(n=8, P=0.40, r^{2}=0.12\right)$. The broken line and solid triangles represent ocean fish feeding primarily on invertebrates: $\log _{10}$ prey length $(\mathrm{mm})=0.35 \log _{10}$ predator length $(\mathrm{cm})-0.13\left(n=48, P=0.0011, r^{2}=0.21\right)$. The dotted line and open circles represent stream piscivores: $\log _{10}$ prey length $(\mathrm{mm})=1.17 \log _{10}$ predator length $(\mathrm{cm})-0.051\left(n=13, P<0.0001, r^{2}=\right.$ $0.81)$. The solid line and open squares represent lake piscivores: $\log _{10}$ prey length $(\mathrm{mm})=1.04 \log _{10}$ predator length $(\mathrm{cm})-0.33(n=60$, $\left.P<0.0001, r^{2}=0.65\right)$. The broken line and open triangles represent ocean piscivores: $\log _{10}$ prey length $(\mathrm{mm})=0.96 \log _{10}$ predator length $(\mathrm{cm})-0.25\left(n=20, P<0.0001, r^{2}=0.66\right)$.

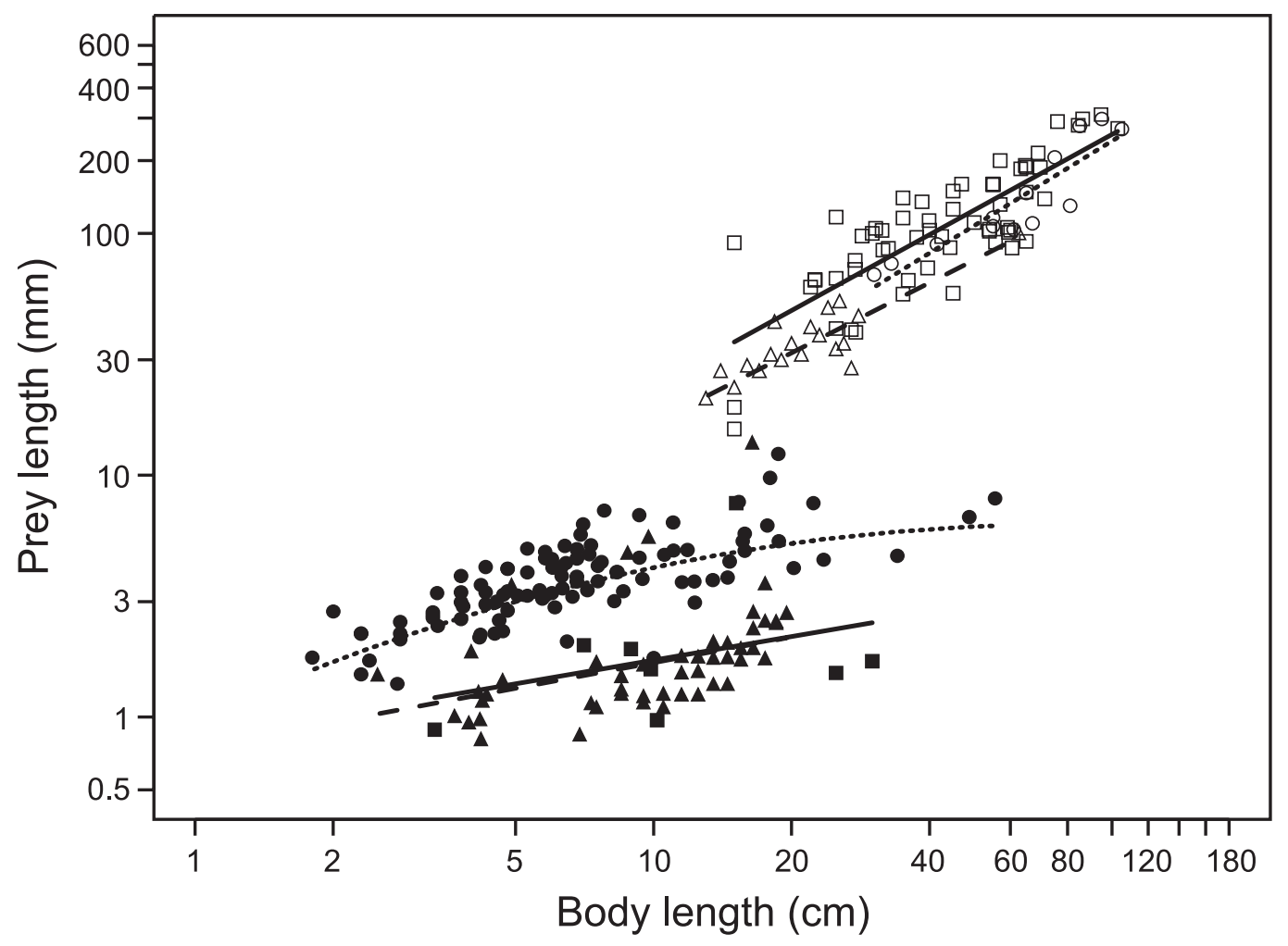

smaller body size in oceans than in lakes, and in lakes than in streams $\left(\chi^{2}=21.031, n=196, P<0.0001\right.$; Fig. $\left.2 a\right)$. The probability of observing a dominant proportion $(\geq 60 \%)$ of fish in the diet also increased with fish size $\left(\chi^{2}=33.74\right.$, $n=196, P<0.0001$; Fig. $2 b)$ but did not differ among habitats $\left(\chi^{2}=1.51, n=196, P=0.22\right)$.

\section{Prey size}

Sixty-one studies provided data for both prey size and fish size (Table 1). In general, the average size of food items in the diet increased with increasing body size of the fish $(r=$ $0.81, n=220, P<0.0001$; Fig. 3 ). There was an obvious difference, however, between the sizes of prey eaten by salmonids specializing on invertebrates versus fish. Piscivorous salmonids ate prey that were at least one order of magnitude longer than invertebrate-eating salmonids (Fig. 3).

In addition, there were differences among habitats in the size of invertebrate-prey consumed. The size of invertebrate prey increased with fish size in all three habitats. This increase was linear in both lakes and oceans (Fig. 3) and did not differ in either slope (analysis of covariance (ANCOVA), $F_{1,55}=0.02, P=0.89$ ) or elevation (ANCOVA, $F_{1,55}=0.01$, $P=0.91)$. The common regression equation for all salmonids in lakes and oceans was $\log _{10}$ prey length $(\mathrm{mm})=0.35 \log _{10}$ predator length $(\mathrm{cm})-0.12\left(n=56, P=0.0009, r^{2}=0.19\right)$.
In streams, however, the increase in invertebrate prey size with increasing fish size followed a quadratic relationship; there appeared to be an asymptotic average prey length of about $6.5 \mathrm{~mm}$ (Fig. 3). Invertebrates eaten by stream salmonids were approximately three times longer than those consumed by fish of equivalent size in lakes and oceans. For example, 99 of 100 data points for stream fish were above the regression for lakes and oceans (binomial test, $P<0.001$ ).

For salmonids that were primarily piscivores, prey size increased linearly with body length in all three habitats (open symbols, Fig. 3). While the three regressions for piscivores did not differ significantly in slope (ANCOVA, $F_{2,92}=0.20$, $P=0.82$ ), they did differ in elevation (ANCOVA, $F_{2,92}=$ 9.05, $P=0.0003$ ). Piscivores in streams and lakes did not differ significantly in the size of prey eaten (adjusted leastsquares means, $P=0.23$ ) but piscivores in oceans ate smaller prey than those in lakes (adjusted least-squares means, $P<0.0001$ ) and streams (adjusted least-squares means, $P=0.049$ ).

\section{Interspecific comparisons}

To test for species-specific differences in prey size, we calculated separate regressions for each species by habitat by prey type (fish or invertebrate) combination with at least 10 observations. Of the 10 separate regressions for nine dif- 
Table 2. Linear regressions of $\log _{10}$ prey size $(\mathrm{mm})$ versus $\log _{10}$ body length $(\mathrm{cm})$ for several salmonid fishes by either an ordinary least-squares (OLS) or a reduced major-axis (RMA) regression technique.

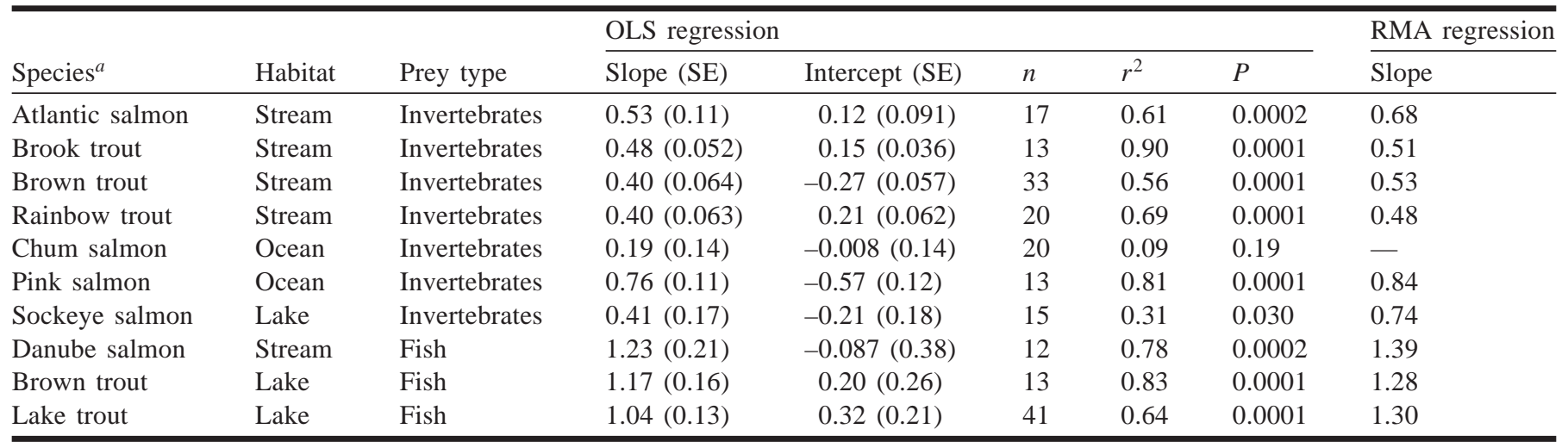

Fig. 4. Comparative allometry of prey size versus predator size for several species of salmonid fishes in streams $(a)$ or lakes and oceans $(b)$ and in comparison with a general equation for animal predators from Cohen et al. (1993). See Table 2 for salmonid regression equations.

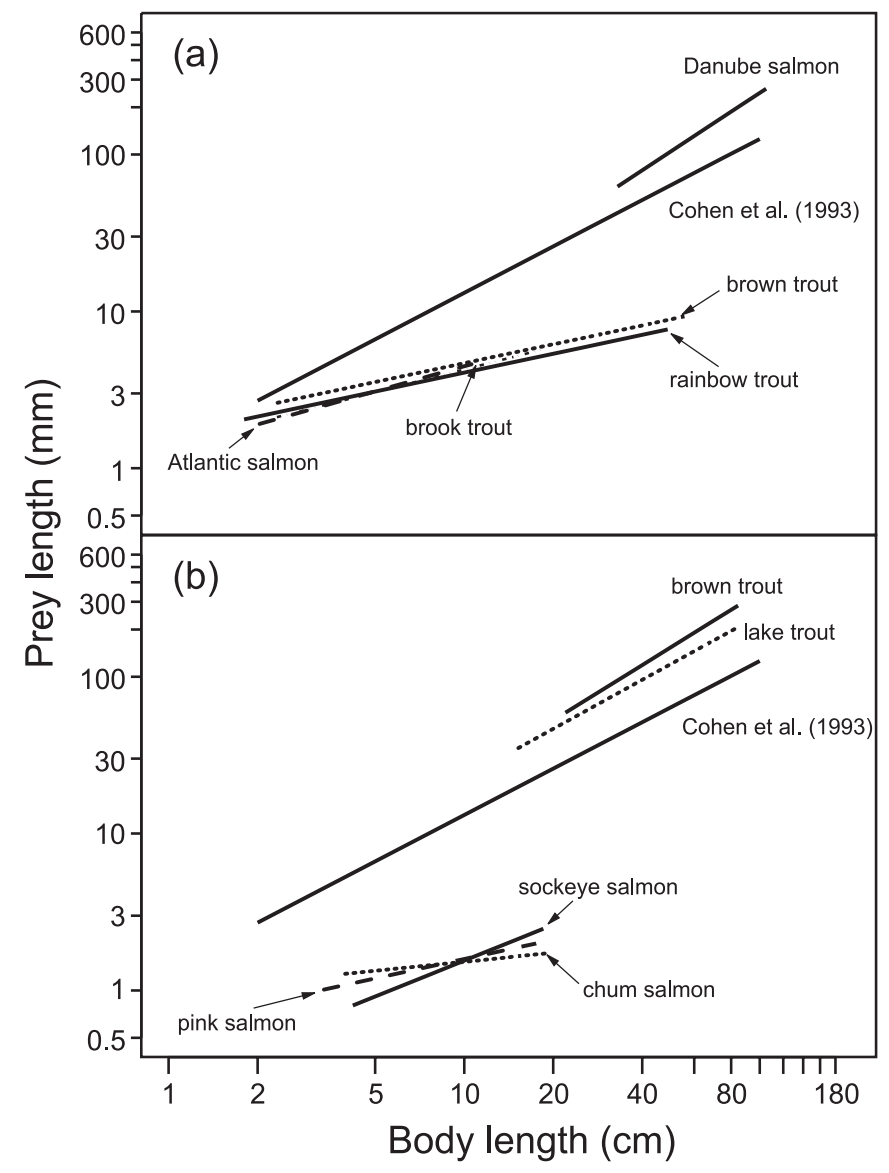

ferent species, prey size increased significantly with fish size in all cases, except for chum salmon (Oncorhynchus keta) (Table 2). Within a habitat type or prey type, there was little evidence of differences among species in prey size (Figs. $4 a$ and $4 b$; Table 2). Using ANCOVA, there were no significant differences in the prey-size versus predator-size relationships for salmonid fishes eating invertebrates in streams (slope, $F_{3,74}=0.44, P=0.73$; elevation, $F_{3,74}=$ $2.57, P=0.061$ ), invertebrates in lakes (slope, $F_{2,42}=2.95$, $P=0.063$; elevation, $\left.F_{2,42}=0.02, P=0.98\right)$, or fish in all habitats (slope, $F_{2,59}=2.15, P=0.13$; elevation, $F_{2,59}=2.10$, $P=0.13$ ).

We also compared our data with Cohen et al.'s (1993) general relationship for prey length versus predator length for a variety of terrestrial and aquatic habitats (RMA regression: $\log _{10}$ prey length $(\mathrm{cm})=0.982 \log _{10}$ predator length (cm) $-0.864 ; 95 \%$ confidence interval (CI) for the slope $=$ 0.901-1.063). All nine significant slopes for the species regressions in Table 2 differed significantly from Cohen et al.'s (1993) relationship; that is, RMA regression slopes in Table 2 were outside their 95\% CI. The slopes of the allometric prey size relationship for invertebrate-eating salmonids were lower than expected by Cohen et al. (1993), whereas the opposite trend was observed for piscivorous salmonids. The average length of salmonids in our study (geometric mean $=13.67 \mathrm{~cm})$ did not differ significantly from the mean in Cohen et al. (1993) (geometric mean = $9.90 \mathrm{~cm}, t=0.44$, df $=702, P>0.5)$. Invertebrate prey were smaller than expected (binomial test, $P<0.001$ ) by Cohen et al. (1993), whereas fish prey were larger than expected (binomial test, $P<0.001$; Fig. 5).

\section{Morphological constraints and prey size}

The range of mean prey size eaten was generally within the hypothesized constraints of gill-raker spacing and mouth size. Only 10 of 220 observations were smaller than the minimum predicted by Wańkowski's (1979) equation of gillraker spacing for Atlantic salmon, whereas only two of 220 observations were larger than the maximum predicted by Damsgård's (1995) equation for mouth gape in brown trout (Fig. 5). Piscivorous salmonids ate relatively large prey that approached the maximum predicted by Damsgård's (1995) equation (Fig. 5). In contrast, invertebrates eaten in lakes and oceans approached the minimum size predicted by gillraker spacing. Salmonids in streams ate invertebrates that were in the middle of the size spectrum.

\section{Discussion}

Our synthesis of the published literature indicated that salmonid fishes in all three habitats exhibited an ontogenetic 
Fig. 5. Mean prey length in relation to salmonid predator length; symbols are as depicted in Fig. 3. The upper dotted line represents the maximum prey size predicted by Damsgård's (1995) gape-limitation equation for brown trout and the solid line represents a general equation for animal predators from Cohen et al. (1993). The lower dotted line represents the minimum prey size predicted by Wańkowski's (1979) gill raker spacing equation for Atlantic salmon.

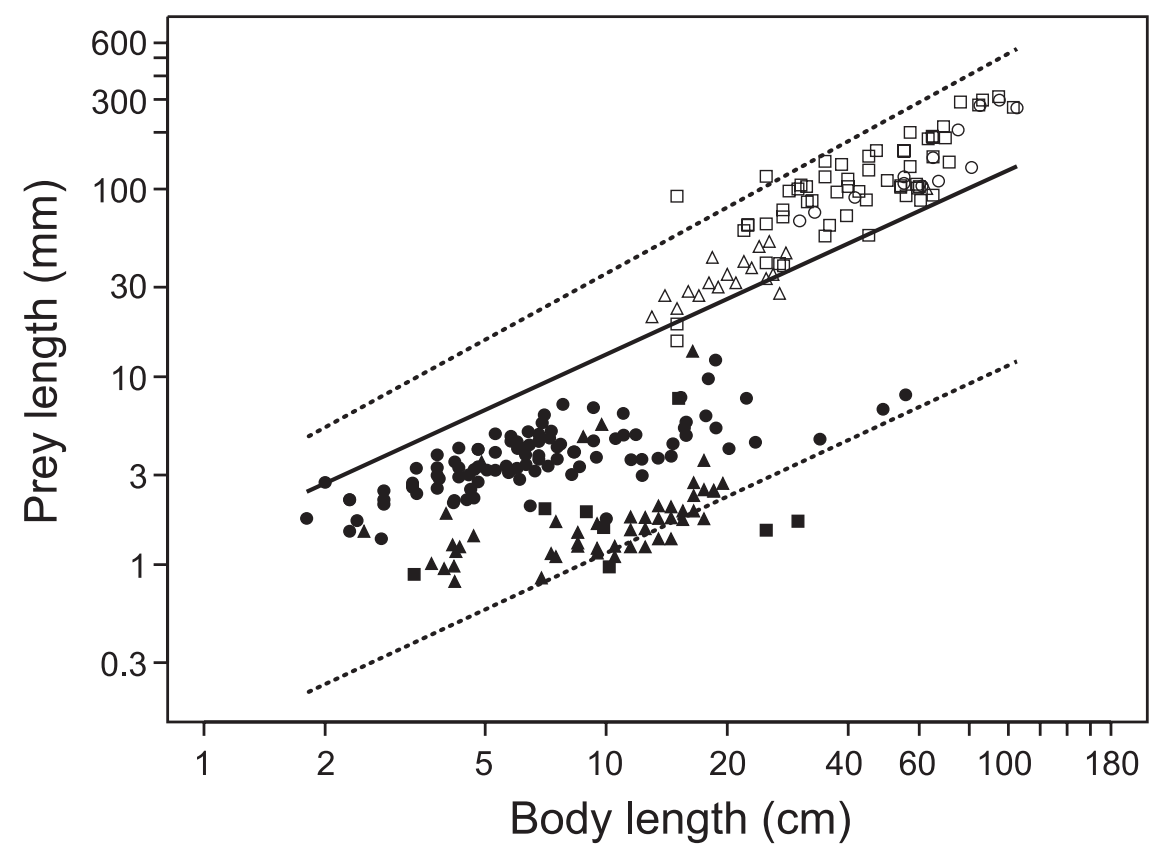

niche shift from feeding on invertebrates when small to feeding on fish when large. Before switching to fish, small salmonids appeared to feed almost exclusively on insects in streams and crustaceans in oceans. The initial feeding niche in lakes was intermediate between streams and oceans. The difference between streams and oceans was not surprising, because insects are abundant in fresh water but are almost absent from marine habitats where they are replaced by crustaceans (Margulis and Schwartz 1998). While crustaceans dominated the diet of small salmonids in lakes, there was a hint of an intermediate feeding niche in which salmonids fed equally on crustaceans and insects before switching to piscivory. These ontogenetic shifts in diet presumably occur as salmonids attempt to eat more energetically profitable prey as they grow larger. As body size increases, optimal prey size also increases as the handling time for larger prey decreases (Wańkowski and Thorpe 1979; Bannon and Ringler 1986). Such ontogenetic shifts have been observed within many populations (Brodeur 1991; L'Abée-Lund et al. 1992).

In contrast with the predictions of the prey-size hypothesis, invertebrate prey were larger in streams than in lakes and oceans and fish prey were smaller in oceans than in streams and lakes. However, salmonids began feeding on fish at a smaller size in oceans than in lakes, and in lakes than in streams, a result that is consistent with the prey-size hypothesis. These habitat differences in the onset of piscivory were likely the result of the availability of suitable forage fish. Because we used the average data from each study, the actual size at which salmonids begin eating fish may be even smaller. Interestingly, salmonids became primarily piscivorous at about $31 \mathrm{~cm}$ in length, regardless of habitat type. Perhaps a greater abundance and a greater range of size of potential forage fish in oceans allow salmonids to begin feeding on fish at a small size and hence grow quickly. By the time a salmonid is $31 \mathrm{~cm}$ in length, invertebrates may no longer be very profitable prey, regardless of habitat type.

The relatively slow growth of salmonids in streams (Bachman 1982; Hutchings 1986) cannot be due to the small size of invertebrate prey, but may be related to the lack of a reliable supply of forage fish. A $15-$ to $20-\mathrm{cm}$ fish is already eating the largest insects that are available in the drift, and will likely begin a steady decline or cessation in growth at about this size unless forage fish are available (Pidgeon 1981; Bannon and Ringler 1986). On average, stream salmonids only begin eating fish when $27 \mathrm{~cm}$ long. When stream salmonids are able to switch to piscivory, they can grow to over $50 \mathrm{~cm}$ in length (Holcík et al. 1988).

The faster growth of salmonids in lakes than in streams is not because the invertebrate prey are larger. Faster growth in lakes may be due to either the higher productivity of invertebrates or the opportunity to begin eating fish at a smaller size (about $15 \mathrm{~cm}$ ). Fast growth to attain a large body size in lake salmonids requires large prey, typically fish, whether they occur naturally (Campbell 1979; Trippel and Beamish 1993) or are introduced (Rasmussen et al. 1990). Planktivorous lake trout eventually cease growth at a small size, even though prey are apparently abundant (Konkle and Sprules 1986). Similarly, the faster growth of salmonids in oceans than in fresh water is not related to the size of invertebrate prey, but may be related to either the higher productivity of the habitat (Gross et al. 1988) or the opportunity to begin eating fish at a small size (at about $8 \mathrm{~cm}$ in length).

In general, habitat type had a greater effect on the size and composition of the diet than did taxonomy. Few differences between species in the allometry of prey size were evident in our broad-scale analysis. The diet of a typical salmonid may be broadly set by its morphology and the availability of prey. The narrow spacing of the gill rakers allows them to eat rela- 
tively small prey compared with most predators of equivalent size (Cohen et al. 1993). Compared with other piscivores, salmonids have small mouths and begin eating fish at a larger size and later age (Mittelbach and Persson 1998). As piscivores, salmonids appear to be gape-limited and increasingly eat larger fish as they grow. Despite their relatively late switch to piscivory, salmonids eat larger prey than expected for a predator of equivalent size (Cohen et al. 1993) and grow larger than expected compared with other piscivores (Mittelbach and Persson 1998).

In summary, our analysis suggests that different species of salmonid fishes represent relatively little variation about a common dietary theme. We suggest that salmonid species of a similar size in a similar habitat will overlap broadly in the size and composition of their diet.

\section{Acknowledgements}

Support for this research was provided by grants from the Natural Sciences and Engineering Research Council of Canada to J.W.A.G., J.D. McPhail, and E.B. Taylor; by funding from le Fonds pour la Formation de Chercheurs et l'Aide à la Recherche du Québec; and by a postdoctoral fellowship from Forest Renewal British Columbia to E.R.K. We thank J.S. Baxter, R.A. Cunjak, L. Sulek, and E.B. Taylor for providing unpublished data. Two anonymous reviewers provided additional helpful comments.

\section{References}

Allan, J.D. 1981. Determinants of diet of brook trout (Salvelinus fontinalis) in a mountain stream. Can. J. Fish. Aquat. Sci. 38: 184-192.

Allan, J.D., and Malmqvist, B.1989. Diel activity of Gammarus pulex (Crustacea) in a south Swedish stream: comparison of drift catches vs. baited traps. Hydrobiologia, 179: 73-80.

Allen, G.H., and Claussen, L.G. 1960. Selectivity of food by brook trout in a Wyoming beaver pond. Trans. Am. Fish. Soc. 89: 8081.

Allen, K.R. 1940. Studies on the biology of the early stages of the salmon (Salmo salar). 2. Feeding habits. J. Anim. Ecol. 10: 4776.

Angradi, T.R., and Griffith, J.S. 1990. Diel feeding chronology and diet selection of rainbow trout (Oncorhynchus mykiss) in the Henry's Fork of the Snake River, Idaho. Can. J. Fish. Aquat. Sci. 47: 199-209.

Bachman, R.A. 1982. A growth model for drift-feeding salmonids: a selective pressure for migration. In Proceedings of the Salmon and Trout Migratory Behavior Symposium, June 3-5, 1981, 1st International Symposium. Edited by E.L. Brannon and E.O. Salo. University of Washington Press, Seattle, Wash. pp. 128-135.

Bailey, J.E., Wing, B.L., and Mattson, C.R. 1975. Zooplankton abundance and feeding habits of fry of pink salmon, Oncorhynchus gorbuscha, and chum salmon, Oncorhynchus keta, in Traitors Cove, Alaska, with speculations on the carrying capacity of the area. Fish. Bull. (Washington, D.C.), 73: 846-861.

Bannon, E., and Ringler, N.H. 1986. Optimal prey size for stream resident brown trout (Salmo trutta): tests of predictive models. Can. J. Zool. 64: 704-713.

Bisson, P.A. 1978. Diel food selection by two sizes of rainbow trout (Salmo gairdneri) in an experimental stream. J. Fish. Res. Board. Can. 35: 971-975.

Bozek, M.A., DeBrey, L.D., and Lockwood, J.A. 1994. Diet overlap among size classes of Colorado River cutthroat trout (Oncorhynchus clarki pleuriticus) in a high-elevation mountain stream. Hydrobiologia, 273: 9-17.

Brodeur, R.D. 1989. Neustonic feeding by juvenile salmonids in coastal waters of the Northeast Pacific. Can. J. Zool. 67: 19952007.

Brodeur, R.D. 1991. Ontogenetic variations in the type and size of prey consumed by juvenile coho, Oncorhynchus kisutch, and chinook, O. tshawytscha, salmon. Environ. Biol. Fishes, 30: 303-315.

Bryan, J.E., and Larkin, P.A. 1972. Food specialization by individual trout. J. Fish. Res. Board Can. 29: 1615-1624.

Cadwallader, P.L., and Eden, A.K. 1981. Food and growth of hatchery-produced chinook salmon, Oncorhynchus tshawytscha (Walbaum), in landlocked Lake Purrumbete, Victoria, Australia. J. Fish Biol. 18: 321-330.

Campbell, R.N. 1979. Ferox trout, Salmo trutta L., and charr, Salvelinus alpinus (L.), in Scottish lochs. J. Fish Biol. 14: 1-29.

Carlander, K.D. 1969. Handbook of freshwater fishery biology. Vol. 1. Iowa State University Press, Ames, Iowa.

Cavalli, L., and Chappaz, R. 1996. Diet, growth and reproduction of the Arctic charr in a high alpine lake. J. Fish Biol. 49: 953 964.

Christie, W.J., Scott, K.A., Sly, P.G., and Strus, R.H. 1987. Recent changes in the aquatic food web of eastern Lake Ontario. Can. J. Fish. Aquat. Sci. 44(Suppl. 1): 37-52.

Cohen, J.E., Pimm, S.L., Yodzis, P., and Saldañas, J. 1993. Body sizes of animal predators and animal prey in food webs. J. Anim. Ecol. 62: 67-78.

Craddock, D.R., Blahm, T.H., and Parente, W.D. 1976. Occurrence and utilization of zooplankton by juvenile chinook salmon in the lower Columbia River. Trans. Am. Fish. Soc. 105: 72-76.

Cunjak, R.A. 1992. Comparative feeding, growth, and movements of Atlantic salmon (Salmo salar) parr from riverine and estuarine environments. Ecol. Freshw. Fish, 1: 26-34.

Damsgård, B. 1995. Arctic charr, Salvelinus alpinus (L.), as prey for piscivorous fish - a model to predict prey vulnerabilities and prey size refuges. Nordic. J. Freshw. Res. 71: 190-196.

Eck, G.W., and Wells, L. 1986. Depth distribution, diet, and overwinter growth of lake trout (Salvelinus namaycush) in Southeastern Lake Michigan sampled in December 1981 and March 1982. J. Gt. Lakes Res. 12: 263-269.

Efford, I.E., and Tsumura, K. 1973. A comparison of the food of salamanders and fish in Marion Lake, British Columbia. Trans. Am. Fish. Soc. 102: 33-47.

Eggers, D.M. 1982. Planktivore preference by prey size. Ecology, 63: 381-390.

Egglishaw, H.J. 1967. The food, growth and population structure of salmon and trout in two streams in the Scottish Highlands. Department of Fisheries and Agriculture for Scotland, Freshw. Salmon Fish. Res. No. 38. Her Majesty's Stationary Office, Edinburgh, Scotland.

Elliott, J.M. 1967. The food of the trout (Salmo trutta) in a Dartmoor stream. J. Appl. Ecol. 4: 59-71.

Elrod, J.S., and O'Gorman, R. 1991. Diet of juvenile lake trout in southern Lake Ontario in relation to abundance and size of prey fishes, 1979-1987. Trans. Am. Fish. Soc. 120: 290-302.

Emmett, R.L., Miller, D.R., and Blahm, T.H. 1986. Food of juvenile chinook, Oncorhynchus tshawytscha, and coho, O. kisutch, salmon off the Northern Oregon and Southern Washington Coasts, MaySeptember 1980. Calif. Fish Game, 72: 38- 46.

Feller, R.J., and Kaczynski, V.W. 1975. Size selective predation by juvenile chum salmon (Oncorhynchus keta) on epibenthic prey in Puget Sound. J. Fish. Res. Board. Can. 32: 1419-1429.

Field-Dodgson, M.S. 1988. Size characteristics and diet of emer- 
gent chinook salmon in a small, stable, New Zealand stream. J. Fish Biol. 32: 27-40.

Frost, W.E., and Smyly, W.J.P. 1952. The brown trout of a moorland fishpond. J. Anim. Ecol. 21: 62-86.

Furukawa-Tanaka, T. 1985. The ecology of salmonid fishes in Japanese mountain streams I. Food condition and feeding habit of Japanese charr, Salvelinus leucomaenis (Pallas). Jpn. J. Ecol. 35: 481-504.

Garman, G.C., and Nielsen, L.A. 1982. Piscivory by stocked brown trout (Salmo trutta) and its impact on the nongame fish community of Bottom Creek, Virginia. Can. J. Fish. Aquat. Sci. 39: $862-869$.

Gerke, R.J., and Kaczynski, V.W. 1972. Food of juvenile pink and chum salmon in Puget Sound, Washington. Wash. Dep. Fish. Tech. Rep. No. 10.

Glova, G.J., and Sagar, P.M. 1991. Dietary and spatial overlap between stream populations of a native and two introduced fish species in New Zealand. Aust. J. Mar. Freshw. Res. 42: 423-433.

Glova, G.J., Sagar, P.M., and Näslund, I. 1992. Interaction for food and space between populations of Galaxias vulgaris Stokell and juvenile Salmo trutta L. in a New Zealand stream. J. Fish Biol. 41: 909-925.

Godin, J.-G.J. 1981. Daily patterns of feeding behavior, daily rations, and diets of juvenile pink salmon (Oncorhynchus gorbuscha) in two marine bays of British Columbia. Can. J. Fish. Aquat. Sci. 38: $10-15$.

Gross, M.R. 1987. Evolution of diadromy in fishes. Am. Fish. Soc. Symp. 1: 14-25.

Gross, M.R., Coleman, R.C., and McDowall, R. 1988. Aquatic productivity and the evolution of diadromous fish migration. Science (Washington, D.C.), 239: 1291-1293.

Gulseth, O.A., and Nilssen, K.J. 1999. Growth benefit from habitat change by juvenile high-Arctic char. Trans. Am. Fish. Soc. 128: 593-602.

Healey, M.C. 1991. Diets and feeding rates of juvenile pink, chum, and sockeye salmon in Hecate Strait, British Columbia. Trans. Am. Fish. Soc. 120: 303-318.

Hoar, W.S. 1976. Smolt transformation: evolution, behavior, and physiology. J. Fish. Res. Board Can. 33: 1234-1252.

Hodgson, J.R., Hodgson, C.J., and Brooks, S.M. 1991. Trophic interaction between largemouth bass (Micropterus salmoides) and rainbow trout (Oncorhynchus mykiss) in a manipulated lake. Can. J. Fish. Aquat. Sci. 48: 1704-1712.

Holcík, J., Hensel, K., Nieslanik, J., and Skácel, L. 1988. The Eurasian huchen, Hucho hucho, largest salmon of the world. Dr. W. Junk, Dordrecht, The Netherlands.

Hubert, W.A., and Rhodes, H.A. 1992. Sizes of prey consumed by age-0 brown trout in Douglas Creek, Wyoming. J. Freshw. Ecol. 7: 277-282.

Hubert, W.A., Gipson, R.D., McDowell, R.A., and Stewart, A.C. 1994. Diet of Eagle Lake rainbow trout in Lake DeSmet, Wyoming. N. Am. J. Fish. Manag. 14: 457-459.

Hudson, P.L., Savino, J.F., and Bronte, C.R. 1995. Predator-prey relations and competition for food between age- 0 lake trout and slimy sculpins in the Apostle Island region of Lake Superior. J. Gt. Lakes Res. 21: 445-457.

Hunt, P.C., and Jones, J.W. 1972. The food of the brown trout in Llyn Alaw, Anglesey, North Wales. J. Fish Biol. 4: 333-352.

Hutchings, J.A. 1986. Lakeward migrations by juvenile Atlantic salmon, Salmo salar. Can. J. Fish. Aquat. Sci. 43: 732-741.

Irie, T. 1987. Ecological studies on juvenile chum and pink salmons in their early marine life-V. Feeding habits and prey size of juvenile chum salmon in Small Harbour in Eastern Hokkaido. Bull. Hokkaido Reg. Fish. Res. Lab. 51: 1-10.
Irvine, J.R., and Northcote, T.G. 1982. Significance of sequential feeding patterns of juvenile rainbow trout in a large lake-fed river. Trans. Am. Fish. Soc. 111: 446-452.

Johnson, J.H., and Ringler, N.H. 1981. Predation on immature midges by recently emerged coho salmon. N.Y. Fish Game J. 28: 121.

Kaczynski, V.W., Feller, R.J., and Gerke, R.J. 1973. Trophic analysis of juvenile pink and chum salmon (Oncorhynchus gorbuscha and O. keta) in Puget Sound. J. Fish. Res. Board. Can. 30: 1003-1008.

Keeley, E.R., and Grant, J.W.A. 1997. Allometry of diet selectivity in juvenile Atlantic salmon (Salmo salar). Can. J. Fish. Aquat. Sci. 54: 1894-1902.

Kerr, S.R. 1971. Prediction of growth efficiency in nature. J. Fish. Res. Board. Can. 28: 809-814.

Kjelson, M.A., Raquel, P.F., and Fisher, F.W. 1982. Life history of fall-run juvenile chinook salmon, Oncorhynchus tshawytscha, in the Sacramento - San Joaquin Estuary, California. In Estuarine comparisons. Edited by V.S. Kennedy. Academic Press, New York. pp. 393-411.

Kocik, J.F., and Taylor, W.M. 1987. Diet and movement of age 1+ pink salmon in western Lake Huron. Trans. Am. Fish. Soc. 116: 628-633.

Konkle, B.R., and Sprules, W.G. 1986. Planktivory by stunted lake trout in an Ontario lake. Trans. Am. Fish. Soc. 115: 515-521.

L'Abée-Lund, J.H., Langeland, A., and Sægrov, H. 1992. Piscivory by brown trout Salmo trutta L., and Arctic charr Salvelinus alpinus (L.) in Norwegian lakes. J. Fish Biol. 41: 91-101.

LaVoie, W.J., IV, and Hubert, W.A. 1994. Use of drifting invertebrates by young-of-the-year brown trout in stream-margin habitat. J. Freshw. Ecol. 9: 37-43.

Magnan, P., and Fitzgerald, G.J. 1982. Resource partitioning between brook trout (Salvelinus fontinalis Mitchill) and creek chub (Semotilus atromaculatus Mitchill) in selected oligotrophic lakes of southern Quebec. Can. J. Zool. 60: 1612-1617.

Malmquist, H.J., Snorrason, S.S., Skúlason, S., Jonsson, B., Sandlund, O.T., and Jónasson, P.M. 1992. Diet differentiation in polymorphic Arctic charr in Thingvallavatn, Iceland. J. Anim. Ecol. 61: 21-35.

Margulis, L., and Schwartz, K.V. 1998. Five kingdoms. 3rd ed. W.H. Freeman, New York.

Martin, N.V. 1970. Long-term effects of diet on the biology of the lake trout and the fishery in Lake Opeongo, Ontario. J. Fish. Res. Board. Can. 27: 125-126.

Mason, J.C. 1974. Behavioral ecology of chum salmon fry (Oncorhynchus keta) in a small estuary. J. Fish. Res. Board. Can. 31: 83-92.

McArdle, B.H. 1988. The structural relationship: regression in biology. Can. J. Zool. 66: 2329-2339.

McLaughlin, R.L., Grant, J.W.A., and Kramer, D.L. 1994. Foraging movements in relation to morphology, water-column use, and diet for recently emerged brook trout (Salvelinus fontinalis) in still water pools. Can. J. Fish. Aquat. Sci. 51: 268-279.

McLennan, J.A., and MacMillan, B.W.H. 1984. The food and brown trout in the Mohaka and other rivers of Hawke's Bay, New Zealand. N.Z. J. Mar. Freshw. Res. 18: 143-158.

Merkel, T.J. 1957. Food habits of the king salmon Oncorhynchus tshawytscha (Walbaum), in the vicinity of San Francisco, California. Calif. Fish Game, 43: 249- 270.

Metz, J.-P. 1974. Die invertebratendrift an der oberfläche eines voralpenflusses und ihre selektive ausnutzung durch die regenbogenforellen (Salmo gairdneri). Oecologia, 14: 247-267.

Miller, M.A., and Holey, M.E. 1992. Diets of lake trout inhabitating nearshore and offshore Lake Michigan environments. J. Gt. Lakes Res. 18: 51-60. 
Mittelbach, G.G., and Persson, L. 1998. The ontogeny of piscivory and its ecological consequences. Can. J. Fish. Aquat. Sci. 55: 1454-1465.

Moore, J.W., and Moore, I.A. 1974. Food and growth of Arctic char, Salvelinus alpinus (L.), in the Cumberland Sound area of Baffin Island. J. Fish Biol. 6: 79-92.

Morgan, R.I.G., Greenstreet, S.P.R., and Thorpe, J.E. 1986. First observations on distribution, food and fish predators of post-smolt Atlantic salmon, Salmo salar, in the outer Firth of Clyde. ICES (Int. Counc. Explor. Sea), Anadromous and Catadromous Fish Committee, CM 1986/M:27.

Mundie, J.H. 1971. The diel drift of Chironomidae in an artifical stream and its relation to the diet of coho salmon fry, Oncorhynchus kisutch (Walbaum). Can. Entomol. 103: 289-297.

Murphy, M.L., Thedinga, J.F., and Koski, K.V. 1987. Size and diet of juvenile Pacific salmon during seaward migration through a small estuary in southern Alaska. Fish. Bull. (Washington, D.C.) 86: $213-222$.

Nagy, S. 1976. Contribution to the knowledge of the food of the huchen (Hucho hucho) (Teleostei: Salmonidae). Zool. Listy, 25: 183-191.

Nakano, S. 1995. Individual differences in resource use, growth and emigration under the influence of a dominance hierarchy in fluvial red-spotted masu salmon in a natural habitat. J. Anim. Ecol. 64: 75-84.

Northcote, T.G. 1991. Success, problems and control of introduced mysid populations in lakes and reservoirs. Am. Fish. Soc. Symp. 9: $5-16$.

Northcote, T.G., Johnston, N.T., and Tsumura, K. 1979. Feeding relationships and food web structure of lower Fraser River fishes. Tech. Rep. No. 16 of the Westwater Research Centre, The University of British Columbia, Vancouver.

O'Donoghue, C.H., and Boyd, E.M. 1932. A second investigation of the food of the sea trout (Salmo trutta). Fishery Board for Scotland, Salmon Fisheries No. 2. Her Majesty's Stationary Office, Edinburg, Scotland.

Olson, R.A., Winter, J.D., Nettles, D.C., and Haynes, J.M. 1988. Resource partitioning in summer by salmonids in south-central Lake Ontario. Trans. Am. Fish. Soc. 117: 552-559.

Parkinson, E.A., Hume, J.M.B., and Dolighan, R. 1989. Size selective predation by rainbow trout on two lacustrine Oncorhynchus nerka populations. Fisheries Management Rep. 94, Province of British Columbia. B.C. Ministry of Fisheries, 2204 Main Mall, Vancouver, B.C.

Pearcy, W.G., Brodeur, R.D., and Fisher, J.P. 1990. Distribution and biology of juvenile cutthroat trout Oncorhynchus clarki clarki and steelhead $O$. mykiss in coastal waters off Oregon and Washington. Fish. Bull. (Washington, D.C.), 88: 697-711.

Peterson, W.T., Brodeur, R.D., and Pearcy, W.G. 1982. Food habits of juvenile salmon in the Oregon Coastal Zone, June 1979. Fish. Bull. (Washington, D.C.), 80: 841-851.

Pidgeon, R.W.J. 1981. Diet and growth of rainbow trout, Salmo gairdneri Richardson, in two streams on the New England Tableland, New South Wales. Aust. J. Mar. Freshw. Res. 32: 967-974.

Randall, R.G., Healey, M.C., and Dempson, J.B. 1987. Variability in length of freshwater residence of salmon, trout, and char. Am. Fish. Soc. Symp. 1: 27-41.

Rasmussen, J.B., Rowan, D.J., Lean, D.R.S., and Carey, J.H. 1990. Food chain structure in Ontario lakes determines PCB levels in lake trout (Salvelinus namaycush) and other pelagic fish. Can. J. Fish. Aquat. Sci. 47: 2030-2038.

Reid, G.M. 1961. Stomach content analysis of troll-caught king and coho salmon, Southeastern Alaska, 1957-1958. U.S. Fish Wildl. Serv. Spec. Sci. Rep. Fish. No. 379.
Reimchen, T.E. 1990. Size-structured mortality in a threespine stickleback (Gasterosteus aculeatus) - cutthroat trout (Oncorhynchus clarki) community. Can. J. Fish. Aquat. Sci. 47: 1194-1205.

Ricker, W.E. 1937. The food and the food supply of sockeye salmon (Oncorhynchus nerka Walbaum) in Cultus Lake, British Columbia. J. Biol. Board Can. 3: 450-465.

Rondorf, D.W., Gray, G.A., and Fairley, R.B. 1990. Feeding ecology of subyearling chinook salmon in riverine and reservoir habitats of the Columbia River. Trans. Am. Fish. Soc. 119: 1624.

Rose, G.A. 1986. Growth decline in subyearling brook trout (Salvelinus fontinalis) after emergence of rainbow trout (Salmo gairdneri). Can. J. Fish. Aquat. Sci. 43: 187-193.

Sagar, P.M., and Eldon, G.A. 1983. Food and feeding of small fish in the Rakaia River, New Zealand. N.Z. J. Mar. Freshw. Res. 17: 213-226.

Sagar, P.M., and Glova, G.J. 1987. Prey preferences of a riverine population of juvenile chinook salmon, Oncorhynchus tshawytscha. J. Fish Biol. 31: 661-673.

Schneindervin, R.W., and Hubert, W.A 1987. Diet overlap among zooplanktophagous fishes in Flaming Gorge Reservoir, WyomingUtah. N. Am. J. Fish. Manage. 7: 379-385.

Scott, W.B., and Crossman, E.J. 1973. Freshwater fishes of Canada. Bull. Fish. Res. Board. Can. No.184.

Sokal, R.R., and Rohlf, F.J. 1995. Biometry. 3rd ed. W.H. Freeman \& Co., New York.

Swedberg, D.V., and Peck, J.W. 1984. Food of the young-of-the-year lake trout (Salvelinus namaycush) in Presque Isle Harbor, Lake Superior. J. Gt. Lakes Res. 10: 280-285.

Tabor, R., Luecke, C., and Wurtsbaugh, W. 1996. Effects of Daphnia availability on growth and food consumption of rainbow trout in two Utah reservoirs. N. Am. J. Fish. Manag. 16: 591-599.

Thonney, J.-P., and Gibson, R.J. 1989. Feeding strategies of brook trout, Salvelinus fontinalis, and juvenile Atlantic salmon, Salmo salar, in a Newfoundland river. Can. Field-Nat. 103: 48-56.

Tippets, W.E., and Moyle, P.B. 1978. Epibenthic feeding by rainbow trout (Salmo gairdneri) in the McCloud River, California. J. Anim. Ecol. 47: 549-559.

Trippel, E.A., and Beamish, F.W.H. 1993. Multiple trophic level structuring in Salvelinus-Coregonus assemblages in boreal forest lakes. Can. J. Fish. Aquat. Sci. 50: 1442-1455.

Van Oosten, J., and Deason, H.J. 1937. The food of the lake trout (Cristivomer namaycush namaycush) and of the lawyer (Lota maculosa) of Lake Michigan. Trans. Am. Fish. Soc. 67: 155-177.

Van Vliet, W.H., and Qadri, S.U. 1970. Capture, morphology and food of lake charr alevins in Lake Heney, Quebec. Can. Field-Nat. 84: 177-179.

Wańkowski, J.W.J. 1979. Morphological limitations, prey size selectivity, and growth response of juvenile Atlantic salmon, Salmo salar. J. Fish Biol. 14: 89-100.

Wańkowski, J.W.J., and Thorpe, J.E. 1979. The role of food particle size in the growth of juvenile Atlantic salmon (Salmo salar L.). J. Fish Biol. 14: 351-370.

Werner, E.E., and Gilliam, J.F. 1984. The ontogenetic niche and species interactions in size-structured populations. Annu. Rev. Ecol. Syst. 15: 393-425.

Wilzbach, M.A., Cummins, K.W., and Hall, J.D. 1986. Influence of habitat manipulations on interactions between cutthroat trout and invertebrate drift. Ecology, 67: 898-911.

Witkowski, A., and Kowalewski, M. 1984. Food of the Danube salmon Hucho hucho (L.) introduced into the River Dunajec. Acta Hydrobiol. 25/26: 205-214.

Wolf, E.G., Morson, B., and Fucik, K.W. 1983. Preliminary studies 
of food habits of juvenile fish, China Poot Marsh and Potter Marsh, Alaska, 1978. Estuaries, 6: 102-114.

Wurtsbaugh, W.A., Brocksen, R.W., and Goldman, C.R. 1975. Food and distribution of underyearling brook and rainbow trout in Castle Lake, California. Trans. Am. Fish. Soc. 104: 88-95.

Yule, D.L., and Luecke, C. 1993. Lake trout consumption and re- cent changes in the fish assemblage of Flaming Gorge Reservoir. Trans. Am. Fish. Soc. 122: 1058-1069.

Økland, F., Jonsson, B., Jensen, A.J., and Hansen, L.P. 1993. Is there a threshold size regulating seaward migration of brown trout and Atlantic salmon? J. Fish Biol. 42: 541-550 